\begin{tabular}{ll}
\hline 論 & 説 \\
\hline
\end{tabular}

反復性中耳炎

茂 木 五郎

\title{
Recurrent Otitis Media
}

\author{
Goro Mogi \\ (Medical College of Oita)
}

Acute (suppurative) otitis media is the most common organic disease of the upper respiratory tract in children, and it recurs often particularly in infants and young children. Recurrent otitis media is of two types: recurrent acute otitis media and recurrent otitis media with effusion. The former is further divided into two groups: one with repeated acute episodes but no symptoms and normal eardrums between episodes; in the other type are superimposed episodes of acute otitis media on otitis media with effusion.

There are several causes of recurrent otitis media: 1) immaturity of the defense systems, such as immunologic, mucociliary, and eustachian tube functions; 2) affinity of bacterial attachment to the nasopharyngeal mucosa; 3) diseases of organs adjacent to the middle ear and eustachian tube; and 4) systemic disorders, i.e., primary immunodeficiency, dysfunction of neutrophils, and immotile-cilia syndrome.

Recurrent otitis media is usually treated by antimicrobial agents with or without myringotomy, and by insertion of a ventilation tube. Although in America and Scandinavian countries antimicrobial prophylaxis or vaccination is used in the treatment of recurrent otitis media, they are not in common use in Japan.

\section{はじめに}

中耳炎は臨床上急性（化膿性）中耳炎, 渗出性中耳炎, および慢性中耳炎に分けられるが, 前二 者は小児上気道で最む多い器質性疾患の一つである。そして低年榆の小児ほよ゙反復し易い特長が ある. 反復性中耳炎は，一般には急性（化膿性）中耳炎を繰返す埸合を指すが，渗出性中耳炎も反 復する例が多い。急性中耳炎之渗出性中耳炎は, 今日, 臨床上の相異に基いて以下のように分けら れる，急性中耳炎は耳消，発熱，鼓膜の発赤や膨隆，時には穿孔を生じて耳漏を伴う急性化膿性中 耳炎であり, 渗出性中耳炎は鼓膜に穿孔なく, 鼓公に貯留液をあたらし, 難聴の原因となるが, 急 性感染症状である耳痛や発熱を伴わない中耳炎と定義されている.

反復性中耳炎の定義は必ずしも明確でないが，Howie ら ${ }^{11}$ にれば 6 歳までに 6 回以上のゆ耳炎 
を繰返す埸命を反復性（Otitis-prone）としている。また，Klein ${ }^{2)}$ は 6 ケ月間に 3 闸，12ケ月開 に4问以にの川耳炎に槯患する埸合を反復性帅耳炎とし，予防的抗菌剂投与の対象としている.

表 1 亿示すように，反復性中耳炎は反復性急性（化膿性）小耳炎と反復性渗出性聑炎に分ける

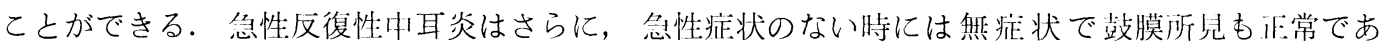
るものと，渗出性け耳炎があってその上に急性化膿性炎を来す場命があり，後者では急性炎症のな い時期でむ難蚛，鼓膜およびインピーダンスオージオメトリーで異常が涩められる.

図 1 は我々の施設で過去 3 作間に治療にあたった急性小耳炎拈よび渗出性中耳炎患者の川耳炎櫂

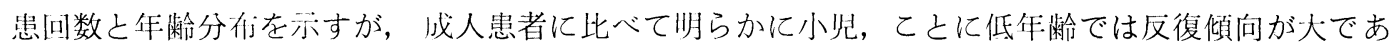

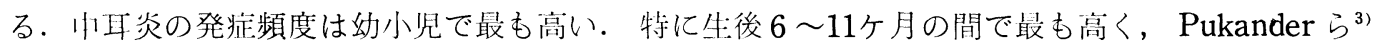
によれば76\%であったという。最初の 1 年間で中耳炎に罹患する率は, Howieら ${ }^{11}$ は $49 \%$ ，Vinther

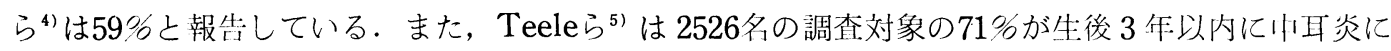

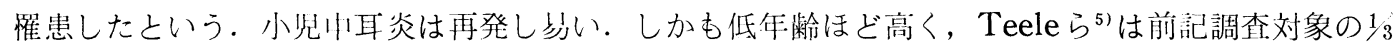

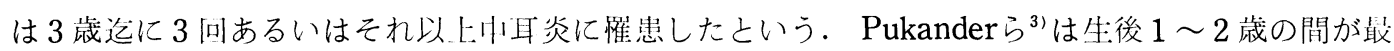
も多いとし，Howie ら ${ }^{11}$ は最初の 1 年以内に中耳炎に櫂患した乳幼児の約半数は次の 1 年閒で再び

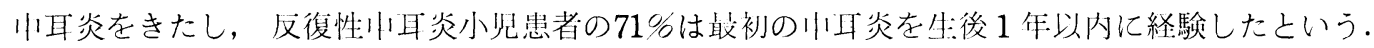
小耳炎は年齢の低い特に䍜患したものほど再発し多いといえる.

表 1 文復性中耳炎
A. 反復性中耳炎
B．反復性渗出性中耳炎

1）急性感染症状のない時期は無症状で鼓膜も正常なタイフ

2) 渗出性中耳炎があってての上に急性化膿性炎が加わるタイプ

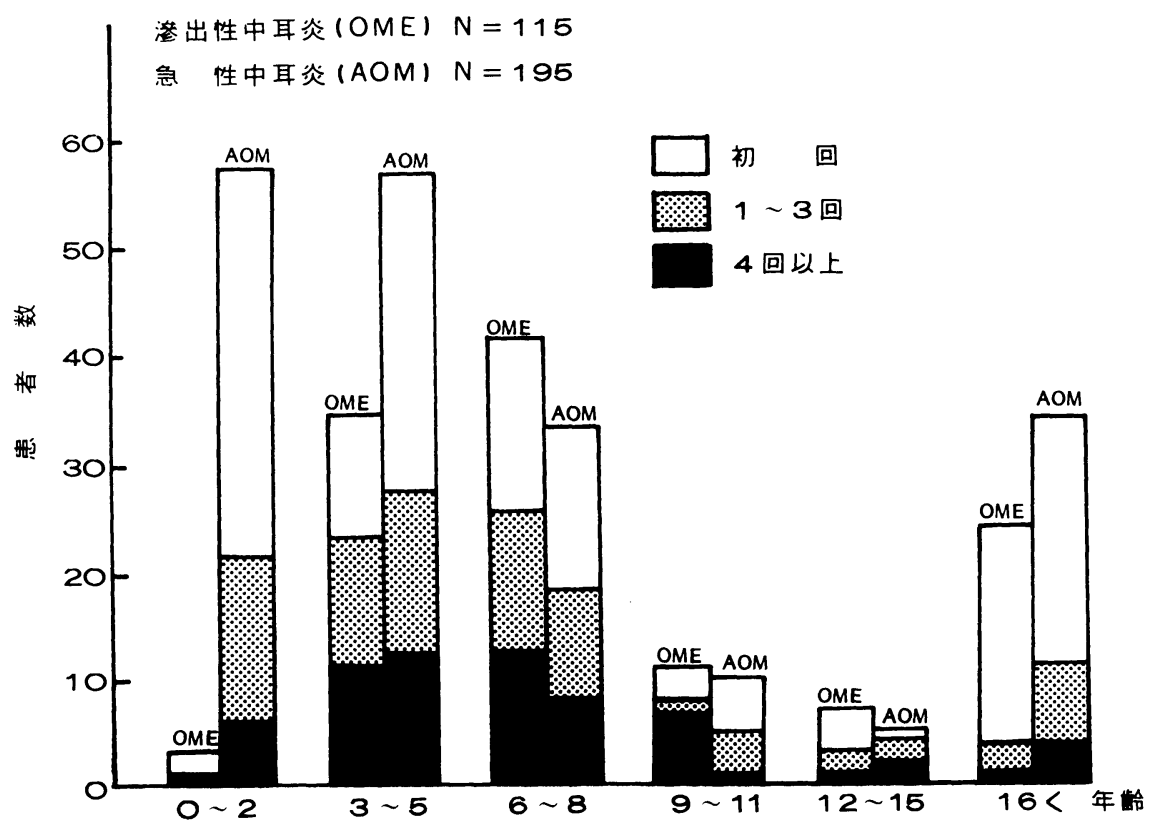

図1 小四炎羅患回数之年粭分布 


\section{反復性中耳炎の要因および背景因子}

このように聑炎は幼小児に多く発生し，し かも再発し婜い。しかしその原因は必ずし屯明 確でないが，表 2 に示されるような要内あるい は背景因子が挙壮られる。

1 生体防御能の未発達：乙れは反復性中耳 炎のみならず，易感染性の大きな原因となる。

1 ) 免疫能の未発達及び一時性不全：全身お よび局所免疫防御能は，生後抗原刺激を受ける ことによって次第に発達してくる. IIII中凭疫グ ロブリンは生後, 徐々に増加する. IgG は姆親 より胎盤を通して新産児に移行するので, 生下 直後の血中濃度は比較的高い, 以後次第に異化 され生後 6 ケ月頃には最も低いレベルとなる. この IgGの生理的減少時期に一致し, 㭃小照乙 とに 6 ケ月から 2 歳迄の期閒にインフルエンザ 菌や肺炎球菌感染を受け易く ${ }^{6)}$, 促って急性川 耳炎羅患率屯高くなる，ヒト IgGは 4 つのサ ブクラス, $\mathrm{IgG}_{1}, \mathrm{IgG}_{2}, \mathrm{IgG}_{3}$ および $\mathrm{IgG}_{4}$ があ り, $\mathrm{IgG}_{2}$ の火損が易感染を導く ${ }^{7)}$. IIll 中 $\mathrm{IgG}_{1}$ および $\mathrm{IgG}_{3}$ の生下後の増加は早く, 1 歳将汇は 成人の約 $1 / 2$ のレベルに達するが， $\mathrm{IgG}_{2}$ 抢よび

表 2 反復性中耳炎の要因および背景因子

1. 生体防御能の未発達

免疫能

粘液線毛輸送能

耳管機能

2. 鼻咽腔細菌叢

3 . 周辺藏器の疾患

鼻副鼻腔炎

アデノィド増殖症

鼻咽腔腫煬

気道アレルギー

口蓋裂

4. 系統疾患

免疫不全症

白血球機能不全症

好酸球および好塩基球欠損痽

非運動性線毛症候群
$\mathrm{IgG}_{4}$ は 3 歳時でもこのレベルに達せず，15歳時 で漸く成人レベルに達する ${ }^{8)}$. Polysaccharide

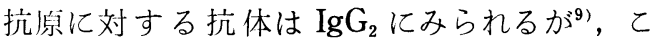
の免疫グロブリンはマクロファージの Fcreceptor に対する親和性は弱く ${ }^{10)}$ ，また補体 活性能む低いという ${ }^{11)}$. Freijdら ${ }^{12)}$ は生後30ケ 月までに 8 〜 17回中耳炎を繰返した反復性中耳 炎群20名と，同じ年齢で，1ないし 2 回のみ川 耳炎罹患をもつ20名の対照群につき，生後12ケ 月と 32 年における血中 $\operatorname{IgG}_{2}$ 濃度を測定した。 反復性中耳炎群では対照群に比へ，血中 $\operatorname{IgG}_{2}$ 浱 度は有意に低下していたてとから， $\mathrm{IgG}_{2}$ の一侍 的不全が反復性中耳炎の原因になっていると推 察した。また反復性中耳炎群で $\operatorname{IgG}_{2}$ 濃度が $0.6 \mathrm{~g}$ /1以下のむのでは， $0.6 \mathrm{~g} / 1$ 以上の群に此べ有息 にインフルェンザ菌感染を来し岁いという。

俔疫応答の主役はリンパ球であるが，それに はT紏胞， B 細胞があり，さらに多くのサブセ ットに分けられる。胸腺の影響を受けたT細胞 は紼胞性免疫の㗢きを司るあののほかに抗体産 生を統御する helper T絊胞と suppressor $\mathrm{T}$ 紼胞がある.Mogiら ${ }^{13)}$ は，1歳から16歳まで の小児患者の未梢血リンパ球 helper T紐胞の $\mathrm{SCW}$ (streptococcal cell wall) に対する増 殖性反応を in vitro で倠察した。加齢之共に 有意に増殖反応性が增すことから, 抗原特異的 负疫応答能は遺伝的統御を受けることが知られ ているが，繰返し抗原刺激を受けることにより

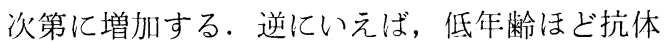
産生細胞の前駆細胞である B 練胞の分化と増列 を支配する $\mathrm{T}$ 練胞の働きの低いことが推察さ れ，幼小児の甥感染性は helper T紏胞レベル の反応性の影響を受けるものと思われる.

川耳貯留液には分泌型 IgAをはじめ他の免度 グロブリン，補体，免疫応答に関するリンパ 球，マクロファージ，多核白血球があり，さら に粘膜には抗体産生絒胞の存在することが知ら れている ${ }^{14)}$ 。このことは，中耳が中耳炎時，局 
所での抗原認識に始る一連の独疫答から抗 原排除までの作用をあつことが推察される。ま た，動物実験においても中耳局所での抗体産生 が認められている ${ }^{15)}$.しかし，滘中耳腔は無 菌であり，小耳粘膜には凭疫に関する細胞はほ とんど認められない，Mogi ら ${ }^{16)}$ はモルモット 小耳粘膜を生下淔後より経日的に観察し，抗体 産生紐胞は他の呼吸上皮や消化管粘膜に比べて 著しく少ないことを知った。しかし，抗原刺激 すれば粘膜には抗体産生:紼胞が多数誘導され る.これらから, 小耳は货疫的には potential organ と云える. 通常は耳管というバリアー があるため, 中耳腔は抗原刺激を受けないが, このバリアーが障害され，紐菌の侵入を受ける 之容易に中耳感染が成立する。すなおち，小耳 局所の免疫防御能が䀛感染性，しいては反復性: 中耳炎の一因と考えられる。

2 ）粘液線毛輸送能: Maedaら ${ }^{17}$ はラットに おいて，中耳および耳管粘膜の線毛および分泌 練胞の分布を胎生期から生後, 経日的に観察 し，これら機能細胞は僅かながら胎生期にすで に認められるが, 生後 1 週間頃から次第に増州 するという。ヒトに执いて新産児や幼少洔の耳 管の粘液線毛輸送能を調べることは難しいが,

Maeda らの形態面からの推察結果は, 中耳お よび耳管の粘液線毛輸送能む個体が外界からの 刺激を受けながら発達するあの之思われ, 従っ て低年齢ほどその機能は未熟であると推察され る.

3 ）耳管機能：耳管は，(1)!耳鼻咽挖から の分泌液の侵入之強大音厈加守る。(2)中耳に 生:じた分泌液を鼻咽腔へ流出させる。(3)中耳腔 之外厈之の換気を行う。(4)中耳腔への細菌, ウ イルスその他異物の侵人を防ぐ。の働きがあ る. Bluestone ${ }^{18}$ は幼少枈で中耳炎槛患率の高 いことやその反復性を耳管機能不全から説明し ている，すなわち，幼少照，てとに 2 歳頃迄で は，耳管軟骨が軟らかすぎてコンプライアンス が大となるため, 耳管開大筋である口蓋張筋が 収縮する時，支持体となるはずの耳管軟骨が同
侍につぶれる状態となるので，耳管が閉寒して しまうという。また，幼少児では頭蓋顔面の発 育不均衡から, |蓋張筋がうまく機能しないて と屯挙げている。このため, 中耳腔什がある程 度以上陰压となった状態で耳管が開くと, 鼻㕧 腔分泌液を中耳腔内一吸込むこととなり，小可 炎を招来すると説明している，Bluestone お よび Cantekin ${ }^{19)}$ は，リスザルの一側の川蓋張 筋を切断すると高度の小耳腔陰压を本じ, 鼓膜 は陷吤する。乙の状態の時, 舅咽腔に肺炎球藏 を加えると切断側に急性小耳炎をみたと報告し ている、川蓋裂患児では，1蓋張筋の機能が誌 く, 急性中耳炎や渗出性中耳炎の合併率が高い が，これは上記実験の䞏床例と考えられ，中耳 腔眝留液があって耳管が開门すると鼻咽腔分泌 液が吸込まれ, 渗出性中耳炎之急性化膿性中耳 炎の反復と合併を米す結果になるとしている。

\section{2 鼻咽腔絊菌叢}

稀な例を除き, 起炎菌が耳管を経て中耳腔に 人り，感染が成立して中耳炎となる，鼻咽腔に おける紐菌之, 耳漏あるいは中耳腔䝪留液にお ける紼菌との比較検討はてれまで多くなされて きたが, Schwartz ら ${ }^{20)}$ によれば, 88\%が一致 していたとする報告と，一致率は $53 \%$ にすぎな いとするものもあり, 前者は鼻咽腔細菌叢を山 耳炎起炎菌として重要視している. Freijd ら ${ }^{21)}$ は反復性中耳炎群 52 名（生後30个月迄に 6 回以 上中耳炎に䍜患）之対照群33名（同期間に 3 [回 以下の雃患）につき鼻咽腔細菌検査を行い, イ ンフルエンザ菌は中耳炎を起している群および 反復性中耳炎群では, 非中耳炎群および対照群 に比べ有意に高率に検出されたととにより, 鼻 㭣腔インフルエンザ菌叢が反復性中耳炎の要因 の一つとして強調している.しかし, Prellner $ら^{22)}$ は鼻咽腔細菌検出率は反復性中耳炎之.正: 常 対照群では有意美はなく, 鼻咽腔における肺炎 球菌, インフルエンザ菌, およびブラファメ一 ラ・カタラーリスの存在は川耳炎のリスク・ファ クターとはならないと述べている。粘膜感染の 第一段階は細菌之上皮細胞之の付着に始まる。 
Anderson ら ${ }^{23)}$ は鼻咽腔上皮細胞之肺炎球菌の in vitro における結合能を検討し, 反復性中耳 炎患者では证: 常対照群に比べ有意に高いとい う. 更に研究努力の必要はあるが, 中耳炎は鼻 眱腔を含め考えねばならず，鼻咽腔細菌叢は中 耳炎の起炎菌の診断, 予後および治療に大きく 関係しているもの之思われる。

\section{3 周辺藏器の疾患}

鼻副鼻腔，咽頭を含めた上気道感染いわゆる 感冒や, 慢性鼻副鼻腔炎, アデノイド増殖症, 鼻咽腔腫煬, 鼻アレルギー, 口蓋裂等の患者で は急性中耳炎や渗出性中耳炎の合併の多いと之 は日常臨床で実感するところである。表 3 は過 去 3 年間著者らの施設で治療にあたった中耳炎 患者のその罹患回数之周辺藏器疾患の関係を示 す。症例数が少なく急性中耳炎では両者の間に 相関は認められないが，渗出性中耳炎では罹患 回数の多い群で合併率が高い傾向がみられる.

Tosら ${ }^{24)}$ や Kuokonen ら ${ }^{25)}$ は鼻腔やアデノ イドにおけるインフルエンザ菌やウイルスの存 在は渗出性中耳炎発症因子であり, 特に反復す る上気道感染は重要な要因之強調している.

Van Cauwenberge および Derycke ${ }^{26)}$ も 2 歳 6 ケ月から 6 歳までの小児 2069 名を調査した結 果, 年間の感冒罹患回数上急性中耳炎罹患率に は極めて高い相関のあることを指摘している。 入, 彼らはティンパノメトリ一検査から，鼻閉 を有する患児，すなわち睡眠時，几呼吸やイビ キの強い小児，鼻漏の多い小児は渗出性中耳炎
の罹患率が高いと報告している.

アデノイド増殖症が中耳炎発症や反復性中耳 炎の原内であるか否かは，まさに賛否両論であ る ${ }^{27)}$. アデノイド増殖症と云っても, 高度の肥 大で鼻閉を伴った典型的なもの，耳管隆起を圧 迫している場合，耳管扁桃が大きく開口部を閉 鎖しているあのから，アデノイドは肥大してい ても耳管への影響の少ないものまでさまざまで ある。乙れら相異が意見の一致をみない原因と 考えられるが，ファイバースコピーが普及しつ つあるので, 詳細は観察のもとでの検討から， いずれ両者の関係は明らかとされるであろう。

以前からアレルギー患者では渗出性中耳炎や 急性中耳炎を招来し岁いことが知られている。 著者らの施設での 3 年間の統計では, 鼓膜切開 によって貯留液の存在を確認した渗出性中耳炎 患者 144 名に気道アレルギー検查を施行し，そ の $24 \%$ 鼻アレルギーの合併をみたが，鼻アレ ルギー患者 659 例に中耳検査を施行し, 鼓膜切 開によって貯留液を確認し得たものは $3 \%$ であ った。このギャップの明確な説明はなし得ない が, 渗出性中耳炎では再発の多い群ほど鼻アレ ルギーの合併率が高かった。昨今の研究結果の 多くはアレルギー，乙とにI型アレルギーで吸 入抗原が中耳腔に入り，直接アレルギー反忍が 中耳腔で生じることに対しては否定的である。 ただ鼻アレルギーでは鼻閉, 耳管開口部粘膜の 腫脹, 易感染性をもたらすので, 中耳炎発症や その反復性を二次的に導びいているもの之考元

表 3 中耳炎罹患回数と周辺蔵器疾患

\begin{tabular}{|c|c|c|c|c|}
\hline 中耳炎罹患回数 & 患者数 & アデノイド増殖症 & 鼻アレルギー & 慢性副鼻腔炎 \\
\hline $\begin{array}{l}\text { 滲中 } \\
\text { 出耳 } \\
\text { 性炎 }\end{array}\left[\begin{array}{l}\text { 初 } \\
1 \sim 3 \\
4 \leqq\end{array}\right.$ & $\begin{array}{l}51 \\
32 \\
30\end{array}$ & $\begin{array}{ll}3 & (6 \%) \\
4 & (13 \%) \\
6 & (20 \%)\end{array}$ & $\begin{array}{cc}7 & (14 \%) \\
10 & (31 \%) \\
10 & (37 \%)\end{array}$ & $\begin{array}{ll}6 & (12 \%) \\
2 & (6 \%) \\
6 & (20 \%)\end{array}$ \\
\hline $\begin{array}{l}\text { 急中 } \\
\text { 性炎 }\end{array}\left[\begin{array}{l}\text { 初 } \\
1 \sim 3 \\
4 \leqq\end{array}\right.$ & $\begin{array}{r}106 \\
53 \\
34\end{array}$ & $\begin{array}{ll}2 & (2 \%) \\
2 & (4 \%) \\
1 & (3 \%)\end{array}$ & $\begin{array}{ll}3 & (3 \%) \\
7 & (13 \%) \\
2 & (6 \%)\end{array}$ & $\begin{array}{cc}12 & (11 \%) \\
5 & (9 \%) \\
2 & (6 \%)\end{array}$ \\
\hline
\end{tabular}


られる。回蓋裂患者に川耳炎やその反復のみら れることは良く知られている。食物が直接耳管 咽頭门を活したり，几蓋張筋の不全がその原因 となっている．粘膜下门蓋裂でも同様に中耳炎 を来す。

反復性:中耳炎は以上のような周辺臓器の異常 を伴うことが多いので，診断治療に祭してその 留意が大切である。

\section{4 系統疾患}

生:体防御能の低下をむたらす系統疗患では, その未発達同様重要な易感染性の背景因子であ る。中耳が生体防御能低下における標的藏器の 一つであることは, 先に述べた如く, 免疫的に は potential organであり，またその解剖学的 特長による。 反復性中耳炎を伴う系統疾患で特 に多いのは免疫不全症, 白血球機能不全症, 非: 運動性線毛症侯群 (immotile-cilia syndrome, Kartagener's syndrome) である.しかし, 中耳だけに感染を来すことはなく，他臟器の感 染や障害を伴う。

\section{1 ) 免疫不全此:}

原発性免疫不全症は表 4 亿示されるように, $\mathrm{B}$ 細胞系， $\mathrm{T}$ 細胞系， $\mathrm{T}, \mathrm{B}$ 練胞複合型免疫不 全症に大別される．我国で1966年から1975年の 10 年閒に，病床数 200 以上の病院の小児科およ び内科へのアンケートによって集計された原発 性免疫不全症は 628 症例であった ${ }^{28)}$. 選択的负 疫グロブリン火症（27\%)，乳先一過性低ガ ンマグロブリンIIII症（19\%)，伴性無ガンマグ ロブリンIlll耀（11\%）の順に多くみられた。い ずれも稀であるが耳鼻咽喉科医の遭遇する问能 性のあるのはB 紐胞系不全, 特に選択的免疫グ ロブリン火椋, 乳児一過性低ガンマグロブリ ンIflli粆，VIＤおよび伴性無ガンマグロブリン 血症である。乙れらはいずれも抗体の火泛，す なわち液性免疫能の低下である。液性免疫は化 膿性感染症に対する防御能を持つ，從ってB䊶 胞系免疫不全症では, 通常インフルエンザ萂, 肺炎球菌，連鎖球菌，ブドウ球菌による反復性: 感染や重症感染を招来する，侍には弱毒菌によ
る opportunistic infection（日よりみ感染） をみることもある。 Mogi および Maeda ${ }^{29)}$ は 8 歳男子で反復性中耳炎を伴ったV I Dを, Kimmerlmann $ら^{30)}$ および Sasaki $~^{311}$ 屯兔疫 不全症と命併した慢性中耳炎例を報告してい る.

若し易感染性の患者，特に頑周な上気道感染 や中耳炎，消化管症状を有する場合には，注意 深い病歷をとり，俔疫不全症が疑われたなら ば，表 5 に示すような検査を施行し，免疫不全 症のタイプを決定し，それに刘する的確な治療 を行う必要がある.

2 ) 多核白血球機能不全盗:

化膿菌（異物）が体内に侵入すると多核日 球はその場所へ遊走し，てれを貪食しようとす る. 貪食作用は紐菌とこれに対する抗体とくに IgG 抗体が結合すると（オプソニン抗体）きわ めて容易となる。乙れは IgGが抗原と絬合する ことによりその Fc 部分が活性化され，乙れに 対し多核白血球がレセプタ一をもつからであ る。しかし，乙の作用屯多核白血球に遊走機能 がないと発揮されない，食作用障害には四段階 がある。すなわち好小球産生：不这，遊走能不

表 4 原発性免疫不全症

1. B 細胞系免疫不全症

伴性無ガンマグロブリン血症（X L A )

選択的免疫グロブリン欠乏症.

IgA, IgM, IgE, IgG subclasses

乳児一過性低ガンマグロブリン血症:

Common variable immunodeficiency

(V I D)

2. T細胞系免疫不全症

DiGeorge syndrome, Nezelof's syndrome 慢性皮虐粘膜カンジダ症

$3 \cdot T \cdot B$ 細胞系複合免疫不全症: 重症複合免疫不全症

Wiskott-Aldrich syndrome Ataxia-telangiectasia を伴う免疫不全症 胸腺腫を伴う免疫不全症 
表 5 免疫不全症に対する検查

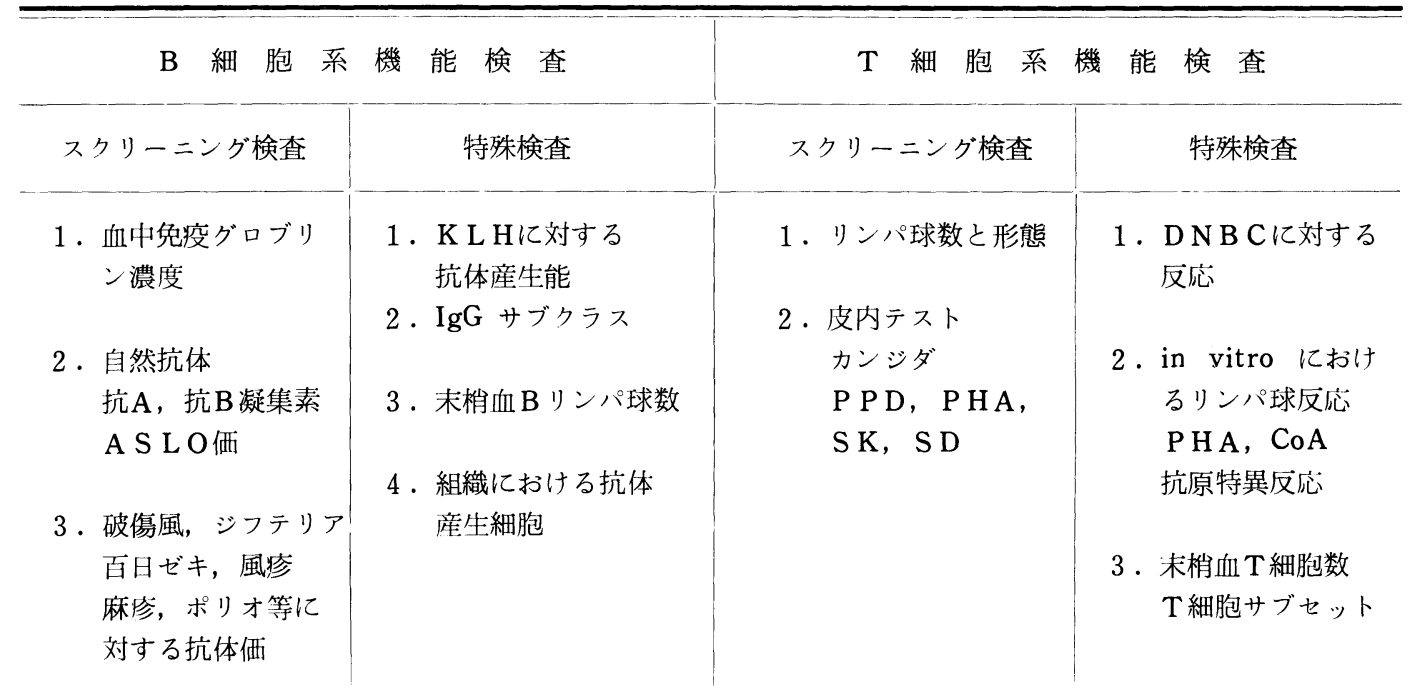

全，攝取不全，および消化不全である ${ }^{32)}$. Hill $ら^{33)}$ は好中球遊走不全を来し, 反復性中耳炎之 慢性下㾥を伴った 14 例を, Sacchi ら ${ }^{34)}$ は同胞 2 名之その父方血族に 7 名の好中球遊走能不全 をもち，中耳炎や他の感染症および下娳を来し た遺伝的家系を，また Bernstein および Gill$\operatorname{man}^{35}$ は, 8 歳女子で渗出性中耳炎之慢性鼻漏 を伴った好中球機能不全（遊走能と食作用）を 報告している。このように下痢に伴った反復性 化膿性炎, ことに反復性中耳炎患者をみた場命 には白血球機能不全症を考虑し，その機能検查 を施行する必要がある。 Juhlin および $\mathrm{Mi}$ chaëlsson ${ }^{36}$ は52歳男子で全身に好酸球および 好塩基球の欠損之小児期より重症呼吸器感染, 㨽鼻腔炎, 中耳炎を来し, 更に気管支喘息之溶 I血性貧仙を伴った稀有な㫌例を報年した。
3 ) 非運動性線毛怔候群 (immotile-cilia syndrome, Kartagener's syndrome)

粘液線毛輸送能は生体にとって柾めて重要な 牛:体防御能であるが, 本症候群はその線毛運動 が不能で, 通常気管支搪張怔之涓鼻腔炎を伴う. 常染色体性少性遺伝性疾患である。本症がしば しば反復性山耳炎をきたすことが報告されてい $ろ^{37) 38}$. Ernstson ら ${ }^{38)}$ は反復性中耳炎を伴っ た6 例を報告したが, 本症候群における中耳炎 は, 渗出性中耳炎に急性化膿性中耳炎を併発す るタイプが多い. 非運動性線毛症候群は 2 万人 に1名の制合にみられる稀な祆患であるが ${ }^{38)}$, 上気道と大気道感染を繰返し，さらに反復性小 炎をみる場命には，本症を念頙に置くべきで あろう。

\section{治療と予防}

急性反復性川耳炎で炡状のない時期は伍: 常な 川耳である場合には, 通常感染時に抗生剂投与 と必要に応じ鼓膜切開が行わ机る. 渗出性小耳 炎に急性感染症状の重なるタイプや反復性渗出 性中耳炎では鼓室 Ventilation tube の留置が
有効之されている ${ }^{39)}$. 勿棆, 背景目子となる状 患が明らかとされた場合や, 調辺藏器に疗患の みられるものには，その治療を行うことは沛す までもない.

我国ではほとんど行われていないが，米国や 
表 6 反復性中耳炎予防における 抗菌剤投与のプロトコール

適恐：6 ケ月間に 3 回, または 12 ケ月間 に 4 回以上の䍜患

薬郕：サルファ剂(sulfisoxazole), 抗生剂 (amoxillin)

投与量：通常の治療量の半量

投与期間：6 ケ月間で冬期から春期

観察：1 月月 1 回

北欧諸国では抗菌剂投与による予防 microbial prophylaxis) が行われている. 表 6 は, Klein'2)のプロトコールを示す。通常， 2 歳以下の乳幼児で効果が大きく，また投与期 間が長期の為, 楽剂は乳奻児が好むもので, 投 与も 1 日 1 回が良いとされている。

もう一つ予防法として欧米で試みられている のがワクチン療法である。肺资予防にはじまっ
表 7 ワクチン沓法に上る反復性中耳炎の予防

一一肺炎球菌多価ワクチン—

臨床効果

動物実験

1) 2 歳以下では有効 中耳局所投与が全身免 性は低いが加柃と＼cjkstart疫より有効 共に効果が増す

2) タイプ 3 には有効

であるがタイプ 6

には効果は低い

\section{おわりに}

次々に優れた抗生物質や抗菌剂が登豩してくる今日でも，川耳炎の発生率は減少せず，乙上に乳 幼児中耳炎は反復性で，また渗出性中耳炎として難聴の一大原因となっている。幼少癿期における 中耳病変は少なからず生涯その人を中耳疾患によって苦しめる．特に反復性中耳炎は難治性の後造 症や合併症を招くので, 適切な予防と治療が必要である。このためには，反復性川耳炎発症の要闪 と背景因子を正しく認識せねばならない.

我国でも抗菌剂やワクチン㓡法による本症の予防法を碓立する必要があり，そのための其礎的， 儖床的研究が望まれる。

本論文の要旨は昭和60年 1 月12日京都市にて行われた国際シンポジウム「渗出性中耳炎」の presymposium “Management of Otitis Media”にて発表した.

\section{文}

1) Howie VM, Ploussard JH and Sloyer J : The "otitis-prone" condition. Am J Dis Child 129: 676 678, 1975.

2) Klein JO: Antimicrobial prophylaxis for recurrent acute otitis media. Pediatr Ann 13:398 403, 1984.

3) Pukander J, Karma P and Sipilä M: Occurrence and recurrence of acute otitis media たこのうj法は1975年から本格的に中耳炎予防に 用いられるようになった ${ }^{40)}$. Howie ら ${ }^{41}$ は肺 炎球菌多価ワクチンを60名の幼児に試み有効で あったとし, Mäkelä ら ${ }^{421}$ は827名の小先に行い, その有効率は $52 \%$ であったいう。 その後, 多 くの人々により試みられており，琴在までの鄁 林および動物実験での結果を要約したのが表 7 である。 
Otol Rhinol Laryngol 89 (Suppl 68, No. 3 , Part 2) : $5 \sim 6,1980$.

6) Pabst $\mathrm{H}$ and Kreth $\mathrm{H}$ : Ontogeny of the immune response as a basis of children disease. J Ped $97: 519 \sim 534,1980$.

7 ) Oxelius $\mathrm{V}:$ Chronic infections in a family with hereditary deficiency of $\mathrm{IgG}_{2}$ and $\mathrm{IgG}_{4}$. Clin Exp Immonol 17:19 27, 1974.

8 ) Oxelius V: IgG subclass levels in infancy and children. Acta Paediatr Scand 68:23 27, 1979.

9 ) Yount W, Dorner M, Kunkel H, et al : Studies on human antibodies. VI Selective variations in subgroup composition and genetic markers. J Exp Med 127:633 646, 1968.

10) Alexander $M$, Andrews $J$, Leslie $R$, et al : The binding of human and guinea pig IgG subclass to homologous macrophage and monocyte Fc receptors. Immunology $35: 115$ $\sim 123,1978$.

11) Ishizaka $T$, Ishizaka $K$, Salmon $S$, et al : Biologic activities of aggregated $r$-globulin. VIII Aggregated immunoglobulins of different classes. J Immunol 99: 82 91, 1967.

12) Freijd A, Oxelius $V$ and Rynnel-Dagöö B : IgG subclass levels in otitis-prone children. In : Recent Advances in Otitis Media with Effusion. ed) Lim, Bluestone, Klein, Nelson. B.C. Decker Inc. Philadelphia, Toronto, pp. $153 \sim 155,1984$.

13) Mogi G, Kawauchi $H$ and Kurono $Y$ : Development of the immune system in children. J Rhinol (in press).

14）茂木五郎：滲出性中耳炎の病態と治療 耳舅咽喉 科領域の最近の進歩. 斉藤成司編集 137〜155， 1984 , 医学教育出版社, 東京.

15) Watanabe N, DeMaria TF, Lewis DM, et al : Experimental otitis media in chinchilla.

II Comparison of the middle ear immune responses to streptococcus pneumoniae Type 3 and Type 23. Ann Otol Rhinol Laryngol 9l (Suppl 93) : 9 16, 1982.

16) Mogi G, Maeda $S$ and Watanabe $N$ : The de- velopment of mucosal immunity in guinea pig midddle ears. Int J Pediatr Otorhinolaryngol | : 331 349, 1980.

17) Maeda S, Mogi $G$ and Oh $M$ : Fine structure of the developing rat middle ear. Ann Otol Rhinol Laryngol 85 (Suppl 31) : $1 \sim 19$, 1976.

18) Bluestone $\mathrm{CD}$ : Eustachian tube function: physiology, pathophysiology, and role of allergy in pathogenesis of otitis media. J Allerg Clin Immunol $72: 242 \sim 251,1983$.

23) Andersson B, Fogh A, J $\phi$ rgensen F, et al : Attachment of streptococcus pneumoniae to human pharyngeal epithelial cells in vitro - mechanism of binding. Otolaryngol, Head Neck Surg $92:$ 266 269, 1984.

24) Tos M, Poulsen G and Borgh J : Etiologic factors in secretory otitis. Arch Otolaryngol $105: 582 \sim 588,1979$.

25) Ruokonen J, Sandelin K and Mäkinen J : Adenoids and otitis media with effusion. Ann Otol Rhinol Laryngol $88: 166 \sim 171,1979$.

26) Van Cauwenberge and Derycke A: The relation between nasal and middle ear pathology. Acta Otorhinolaryngol Belg $37: 830 \sim 841$, 1983.

27) Maw AR : Chronic otitis media with effusion and adenotonsillectomy: A prossective randomized controlled study. In: Recent Advances in Otitis Media with Effusion. (ed) Lim, Bluestone, Klein, Nelson. B.C. Decker Inc. Philadelphia, Toronto, pp. 299 $\sim 302,1984$.

28) Hayakawa H, Iwata T, Yata J, et al : Primary immuno-deficiency syndrome in Japan, I Overriew of a national survey on primary immunodeficiency syndrome. J Clin Immunol I : 31 39, 1981.

29) Mogi G and Maeda S : Recurrent otitis media in association with immunodeficiency. Arch Otolaryngol $108: 203 \sim 207,1982$.

30) Kimmerlmann CP and Potsic WP: Immunodeficiency in pediatric otolaryngology. Am J 
Otolaryngol | : 33 38, 1979.

31) Sasaki CT, Askenase P, Dwyer J, et al: Chronic ear infection in the immunodeficient patient. Arch Otolaryngol 107:82 86, 1981.

32) Stossel TP: Phagocytosis. N Engl J Med 290: 717 723, 774 780, 833 837, 1974.

33) Hill HR, Book LS, Hemming VG, et al: Defective neutrophil chemotactic responses in patients with recurrent episodes of otitis media and chronic diarrhea. Am J Dis Child |3| : 433 436, 1977.

34) Sacchi FT, Ferrai FA, Fortunato A, et al : A defect in neutrophil motility in two siblings with recurrent infections and a remarkable family history. Infection 7 : 45 47, 1979.

35) Bernstein JM and Gillman CF : Phagocytic dysfunction as a cause of recurrent upper respiratory disease. ORL $82: 509 \sim 517$, 1976.

36) Juhlin L and Michaëlsson G: A new syndrome characterized by absence of eosinophilis and basophilis. Lancet I : 1233 1235, 1977.

37) Fischer TJ, McAdams JA, Entis GN, et al : Middle ear ciliary defect in Kartagener's
Syndrome. Pediatrics 62: 443 445, 1978.

38) Ernstson S, Afzelus BA and Mossberg B : Otologic manifestations of the immotile-cilia syndrome. Acta Otolaryngol $97: 83 \sim 92$, 1984.

39) Samuel J, Rosen G and Vered Y: Use of middle ear ventilation tubes in recurrent acute otitis media. J Laryngol Otol $93: 979$ $\sim 981,1979$.

40) Hill JC : Immunization against pneumococcal otitis media : state of the art. In : $\mathrm{Re}^{-}$ cent Advances in Otitis Medis with Effusion. (ed) Lim, Bluestone, Klein, Nelson. B.C. Decker Inc. Philadelphia, Toronto, pp, 249 251, 1984 .

41) Howie VM, Ploussard JH and Sloyer JL: Immunization against recurrent otitis media. Ann Otol Rhinol Laryngol 85 (Suppl 25, No. 2, Part 2) :224 258, 1976.

42) Mäkelä PH, Sibakor M, Herva E, et al Pneumococcal vaccine and otitis media. Lancet $2: 547 \sim 551,1980$.

原稿到着: 昭和 60 年 3 月 4 日
別刷請求先 : 茂木五郎
个879 56 大分県大分郡挾間町医大ケ丘 $1-1506$
大分医科大学耳鼻咽喉科学教室

